\title{
Volatile Compounds Emitted by 'Gala' Apples following Dynamic Atmosphere Storage
}

\author{
J.P. Mattheis and D.A. Buchanan \\ United States Department of Agriculture, Agricultural Research Service, 1104 North Western Avenue, \\ Wenatchee, WA 98801 \\ J.K. Fellman \\ Department of Horticulture and Landscape Architecture, Washington State University, Pullman, WA 99164
}

ADDITIONAL INDEX WORDs. Malus $\times$ domestica, esters, fruit quality, 1-methoxy-(2-propenyl) benzene, ethylene

ARstract. Fruit quality and volatile compounds produced by apple fruit (Malus $\times$ domestica Borkh. 'Gala') were characterized following regular atmosphere (RA) or controlled atmosphere (CA) storage at $1^{\circ} \mathrm{C}$. Static $\mathrm{CA}$ conditions were $1,1.9,2.8$, or $3.7 \mathrm{kPa} \mathrm{O}_{2}$. Fruit stored under dynamic $\mathrm{CA}$ conditions were exposed to ambient air 1,2 , or 3 days per week for 8 hours then returned to $1 \mathrm{kPa} \mathrm{O}_{2}$. All $\mathrm{CA}$ treatments included $2 \mathrm{kPa} \mathrm{CO}_{2}$. Ethylene production was reduced following CA storage plus 1 day at $20^{\circ} \mathrm{C}$ compared with apples stored in RA. Apples stored in static $1 \mathrm{kPa} \mathrm{O}_{2}$ and the dynamic treatments had lower ethylene production compared with apples stored in 1.9 to $3.7 \mathrm{kPa} \mathrm{O}_{2}$ after 90 and 120 days. Ethylene production by apples from all CA treatments recovered during a 7-day poststorage ripening period at $20^{\circ} \mathrm{C}$. Ester production was reduced following $\mathrm{CA}$ at $1 \mathrm{kPa} \mathrm{O}_{2}$ after 60 days compared with RA-stored fruit. Production of butyl acetate by apples stored in $1 \mathrm{kPa} \mathrm{O}_{2}$ static $\mathrm{CA}$ was $29 \%, 30 \%$, and $7 \%$ of that produced by $\mathrm{RA}$-stored fruit after 60, 90, and 120 days storage plus 7 days at $20^{\circ} \mathrm{C}$. Amounts of 2 -methylbutyl acetate were not affected by CA storage, however, production of other 2-methylbutyrate esters was reduced following $1 \mathrm{kPa} \mathrm{O}_{2}$ storage. Ester production increased with $\mathrm{O}_{2}$ concentration after 90 days in storage. The dynamic treatments resulted in greater ester emission after 120 days storage plus 7 days at $20^{\circ} \mathrm{C}$ compared with apples stored in static $1 \mathrm{kPa} \mathrm{O}_{2}$. Production of 1-methoxy-(2-propenyl) benzene by apples subjected to dynamic treatments was also higher after 120 days storage plus 7 days at $20^{\circ} \mathrm{C}$ compared with apples stored in RA or static CA. No differences in firmness, titratable acidity or soluble solids content were observed between apples stored in $1 \mathrm{kPa} \mathrm{O}_{2}$ and the dynamic treatments. Firmness and titratable acidity were maintained better by dynamic treatments compared with static atmospheres containing $>1 \mathrm{kPa} \mathrm{O}_{2}$.

Volatile compounds produced by apples constitute a major portion of fruit aroma. Qualitative and quantitative volatile emission during fruit ripening is determined by a number of factors including fruit maturity at harvest (Brown et al., 1966; Dirinck et al., 1989; Hansen et al., 1992a; Vanoli et al., 1995; Song and Bangerth, 1996; Yahia et al., 1990), storage duration (Willaert et al., 1983; Lidster et al., 1983; Yahia, 1991), and storage atmosphere composition (Streif and Bangerth, 1988; Hansen et al., 1992b; Brackmann et al., 1993). A residual effect of controlled atmosphere (CA) storage of apples is a reduction in volatile production, most notably a reduced emission of esters characteristic of ripening apples (Guadagni et al., 1971; Patterson et al., 1974). The major esters produced by ripening fruit are thought to arise primarily from lipid (Tressl et al., 1970a) and amino acid degradation (Myers et al., 1970; Tressl et al., 1970b), and these pathways are active in ripening apples (Bartley et al., 1985; Hansen and Poll, 1993; Rowan et al., 1996). Production of lipid-derived esters is reduced by low $\mathrm{O}_{2}$ concentrations during CA storage, while esters that arise from amino acid catabolism are negatively impacted by high $\mathrm{CO}_{2}$ (Brackman et al., 1993).

Aroma production during fruit ripening is considered to be an ethylene-mediated response (Abeles et al., 1992). Prolonged CA storage reduces aroma production and may reduce apple sensitivity to ethylene (Bangerth, 1984). Inhibition of ethylene production

Received for publication 16 June 1997. Accepted for publication 15 Dec. 1997 This work was supported in part by a grant from the Washington Tree Fruit Research Commission. Mention of a trademark, proprietary product, or vendor does not constitute a guarantee or warranty of the product by the USDA or Washington State Univ. and does not imply its approval to the exclusion of other products or vendors that also may be suitable. The cost of publishing this paper was defrayed in part by the payment of page charges. Under postal regulations, this paper therefore must be hereby marked advertisement solely to indicate this fact. by aminoethoxyvinylglycine (AVG) also reduces aroma production (Bangerth and Streif, 1987; Halder-Doll and Bangerth, 1987). Transgenic tomato fruit with an antisense ACC oxidase gene do not produce ethylene and the characteristic aroma of ripening fruit is absent (Oeller et al., 1991). Low $\mathrm{O}_{2}$ and high $\mathrm{CO}_{2}$ concentrations reduce transcription of the genes for ACC synthase and ACC oxidase in 'Golden Delicious' apples (Gorny and Kader, 1996) resulting in reduced ethylene production. This body of evidence supports a regulatory role for ethylene in promoting aroma development in climacteric fruit, however, the physiological mechanisms through which ethylene regulates this process are as yet unknown.

Storage duration and atmosphere concentration influence ethylene and ester production after removal from storage (Streif and Bangerth, 1988). Ester production decreases with reduced $\mathrm{O}_{2}$ concentrations, but this CA response can be reduced by increasing the $\mathrm{O}_{2}$ concentration during storage (Smith, 1984; Lidster et al., 1983). Increasing the $\mathrm{O}_{2}$ concentration during storage also reduces firmness retention (Lidster et al., 1983). The success of this type of atmosphere manipulation depends on cultivar and the maturity at which fruit are harvested for CA (Mattheis et al., 1995). Another means to examine the role of storage $\mathrm{O}_{2}$ concentration on poststorage aroma production is to increase $\mathrm{O}_{2}$ for short periods during storage with a subsequent return to the low concentration setpoint. The present study used this dynamic atmosphere manipulation to evaluate production of esters and other volatiles as well as fruit quality of 'Gala' apples after CA storage.

\section{Materials and Methods}

'Gala' apples were harvested from a commercial orchard near Chelan, Wash. Trees ('Gala' on M9 rootstock) were in the sixth 
Table 1. Maturity of 'Gala' apples analyzed $1 \mathrm{~d}$ after harvest. Apples were stored at $20^{\circ} \mathrm{C}$ before analysis. Values are means of 20 individual fruit.

\begin{tabular}{lccccc}
\hline \hline $\begin{array}{l}\text { Mass } \\
(\mathrm{g})\end{array}$ & $\begin{array}{c}\text { Internal } \\
\text { ethylene } \\
\left(\mu \mathrm{mol} \cdot \mathrm{m}^{-3}\right)\end{array}$ & $\begin{array}{c}\text { Starch } \\
\text { index } \\
(1-6)\end{array}$ & $\begin{array}{c}\text { SSC } \\
\left(\mathrm{g} \cdot \mathrm{L}^{-1}\right)\end{array}$ & $\begin{array}{c}\text { TA } \\
\left(\mathrm{mg} \cdot \mathrm{L}^{-1}\right)\end{array}$ \\
\hline $192.7 \pm 26.9$ & $70.4 \pm 3.8$ & $58.5 \pm 22.1$ & $2.7 \pm 1.1$ & $124 \pm 10$ & $3.66 \pm 0.33$ \\
\hline
\end{tabular}

leaf. Apples were selectively harvested $124 \mathrm{~d}$ after full bloom according to background color to obtain a uniform sample. Fruit harvest maturity was determined by analyses of internal ethylene concentration, flesh firmness, soluble solids content, titratable acidity, and estimation of starch scores. Ethylene measurements were performed on gas samples removed from the fruit core (Williams and Patterson, 1962). Gas analyses were conducted isothermally at $50^{\circ} \mathrm{C}$ using a gas chromatograph (HP5880; Hewlett Packard, Avondale, Pa.) equipped with a 50-cm, 0.32-cm-i.d. glass column packed with 80- to 100-mesh Porapak Q (Supelco, Bellefonte, $\mathrm{Pa}$.). The $\mathrm{N}_{2}$ carrier, $\mathrm{H}_{2}$, and air flows were 25,25 , and $300 \mathrm{~mL} \cdot \mathrm{min}^{-1}$, respectively. Flesh firmness was measured on two pared surfaces per fruit using a penetrometer with an 11-mm tip (Lake City Technical, Kelowna, B.C.). Soluble solids content (SSC) and titratable acidity (TA) were determined using freshly prepared juice. Juice was prepared using a Champion juicer (Plastaket Mfg., Lodi, Calif.). SSC was measured using a handheld refractometer (Atago, Tokyo) and TA was determined by titrating $10 \mathrm{~mL}$ juice with $0.1 \mathrm{M} \mathrm{KOH}$ to $\mathrm{pH} 8.2$ using an autotitrator (Radiometer, Copenhagen, Denmark ). The extent of starch hydrolysis was rated visually using a 1 to 6 scale $(1=$ full, $6=$ no starch) after staining an equatorial section of each apple with a 5 $\mathrm{mg} \cdot \mathrm{L}^{-1} \mathrm{I}-\mathrm{KI}$ solution.

Storage chamber atmospheres were established within $48 \mathrm{~h}$ of harvest using compressed air and $\mathrm{CO}_{2}$ plus $\mathrm{N}_{2}$ from a membrane generator (Permea, St. Louis). Chamber gas composition was analyzed at 90 -min intervals and automatically corrected as necessary (Techni-Systems, Chelan, Wash.), therefore chamber atmospheres were static except when adjustments were conducted. Apples were stored in air (RA treatment) or $2.0 \mathrm{kPaCO}_{2}$ with $1,1.9$, 2.8 , or $3.7 \mathrm{kPa} \mathrm{O}_{2}$ at $1{ }^{\circ} \mathrm{C}(\mathrm{CA}$ treatments $)$ in $0.145-\mathrm{m}^{3}$ chambers. Beginning $14 \mathrm{~d}$ after atmospheres were established, doors of selected $1-\mathrm{kPaO}_{2}$ chambers were removed for $8 \mathrm{~h}, 1,2$, or $3 \mathrm{~d}$ per week. The mean $\mathrm{O}_{2}$ concentration in these chambers over the course of CA storage approximated that of the chambers where the $\mathrm{O}_{2}$ setpoint was $1.9,2.8$, or $3.7 \mathrm{kPa}$. After the doors were replaced, chambers were purged with $\mathrm{N}_{2}$, and the $\mathrm{O}_{2}$ and $\mathrm{CO}_{2}$ setpoints (1.0 and $2.0 \mathrm{kPa}$, respectively) were achieved within $4 \mathrm{~h}$. Apples from each treatment were removed from storage after 60,90 , or $120 \mathrm{~d}$ and analyzed after 1 or $7 \mathrm{~d}$ ripening at $20^{\circ} \mathrm{C}$ ( 20 fruit per treatment per storage duration per ripening).

Analysis of volatile compounds was as described previously (Mattheis et al., 1991). Intact fruit $(\approx 1 \mathrm{~kg})$ were placed in $4-\mathrm{L}$ glass jars, then the jars were sealed with Teflon lids. Compressed air passed through traps containing activated charcoal, molecular sieve, Purafil (Purafil Inc., Atlanta), and Tenax GC (Alltech Assoc., Deerfield, Ill.) purged the jars at $100 \mathrm{~mL} \cdot \mathrm{min}^{-1}$ for $1 \mathrm{~h}$ before sampling. Volatile compounds exiting the jars were adsorbed onto $50 \mathrm{mg}$ Tenax GC contained in a glass trap. The traps were subsequently desorbed into a gas chromatograph (HP 5890) using an automated thermal desorption and cryofocusing autosampler (Teckmar Associates, Cincinnati, Ohio). Quantitative and qualitative analyses were performed using a mass selective detector (HP 5971 A; Hewlett Packard, Palo Alto, Calif.). Putative identification was made using the Wiley NBS library and authentic standards were used for confïrmatory identification. Response factors generated using standards were the basis for quantification. Statistical analyses were conducted using SAS (SAS Institute, Cary, N.C.) based on a factorial design (storage treatment $\times$ storage duration $\times$ days ripening after storage). Fischer's least significant difference values were used for mean separations based on significant treatment $\times$ storage duration $\times$ ripening after storage interactions except for ethylene production where data from 1 and $7 \mathrm{~d}$ after removal from storage were analyzed separately.

\section{Results}

Apples were of acceptable maturity at harvest for long-term storage (Plotto et al., 1995; Walsh et al., 1991) based on internal ethylene concentration, starch index, firmness, SSC, and TA (Table 1). RA apples produced the most ethylene $1 \mathrm{~d}$ out of storage (Fig. 1). Ethylene production by apples stored in static atmospheres significantly increased with $\mathrm{O}_{2}$ concentration after 90 and $120 \mathrm{~d}$ in storage plus $1 \mathrm{~d}$ ripening at $20^{\circ} \mathrm{C}$; however, ethylene production by fruit stored in all three dynamic treatments was similar to fruit in static $1 \mathrm{kPaO}_{2}$. Ethylene production increased for all CA treatments during $7 \mathrm{~d}$ ripening at $20^{\circ} \mathrm{C}$ after removal from storage. No effects of storage $\mathrm{O}_{2}$ concentration under static conditions were evident after 60 or $90 \mathrm{~d}$ storage plus $7 \mathrm{~d}$ ripening. Ethylene production by apples stored in $1 \mathrm{kPa} \mathrm{O}_{2}$ was lower than other static treatments after $120 \mathrm{~d}$ storage plus $7 \mathrm{~d}$ ripening. Ethylene production by apples exposed to ambient $\mathrm{O}_{2} 1 \mathrm{~d}$ per week was higher than the other dynamic treatments and apples stored in static $1 \mathrm{kPa} \mathrm{O}_{2}$ after $120 \mathrm{~d}$ storage plus $7 \mathrm{~d}$ ripening.

Twenty straight and branched-chain esters were detected in

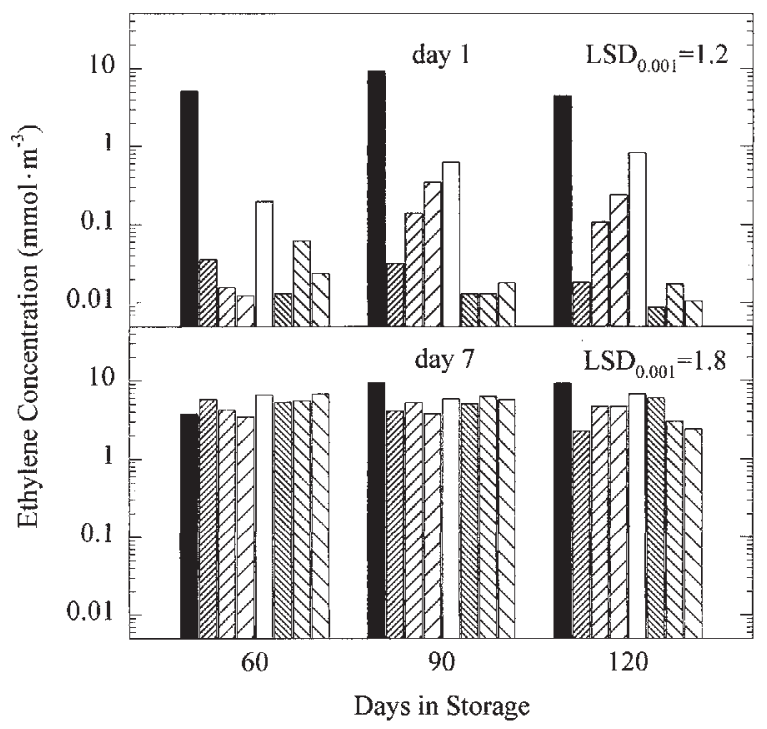

Fig. 1. 'Gala' apple internal ethylene concentration (IEC) $\left(\mathrm{mmol} \cdot \mathrm{m}^{-3}\right)$ following regular atmosphere (RA) or controlled atmosphere (CA) storage. Apples were removed from storage and IEC was determined after 1 or $7 \mathrm{~d}$ at $20^{\circ} \mathrm{C}$. Bars represent mean values based on analysis of 20 individual apples. Fisher's least significant difference values for significant treatment $\times$ storage duration interaction are indicated. 
Table 2. Volatile esters emitted from 'Gala' apples after RA or $\mathrm{CA}\left(1 \mathrm{kPa} \mathrm{O}, 2 \mathrm{kPa} \mathrm{CO}_{2}\right)$ storage plus $7 \mathrm{~d}$ at $20^{\circ} \mathrm{C}$. Values $\left(\mu \mathrm{mol} \cdot \mathrm{m}^{-3}\right)$ are means $\pm \mathrm{SE}$ of dynamic headspace samples collected from four $1-\mathrm{kg}$ replications.

\begin{tabular}{|c|c|c|c|c|c|c|}
\hline \multirow[b]{2}{*}{ Compound } & \multicolumn{6}{|c|}{ Storage duration (d) } \\
\hline & RA & $\mathrm{CA}$ & RA & $\mathrm{CA}$ & RA & $\mathrm{CA}$ \\
\hline Butyl acetate & $48.4 \pm 1.5$ & $13.9 \pm 2.3$ & $67.7 \pm 1.7$ & $20.5 \pm 2.3$ & $46.1 \pm 1.1$ & $3.39 \pm 0.48$ \\
\hline Pentyl acetate & $1.43 \pm 0.06$ & $0.80 \pm 0.09$ & $3.06 \pm 0.15$ & $1.47 \pm 0.14$ & $0.65 \pm 0.06$ & $0.28 \pm 0.03$ \\
\hline Hexyl acetate & $13.6 \pm 1.1$ & $8.22 \pm 0.64$ & $31.1 \pm 1.3$ & $14.0 \pm 1.6$ & $10.3 \pm 1.0$ & $4.08 \pm 0.51$ \\
\hline Hexyl propanoate & $1.05 \pm 0.16$ & $0.50 \pm 0.04$ & $2.74 \pm 0.19$ & $0.92 \pm 0.09$ & $0.81 \pm 0.08$ & $0.32 \pm 0.03$ \\
\hline Butyl butyrate & $2.17 \pm 0.28$ & $0.64 \pm 0.09$ & $4.85 \pm 0.29$ & $1.30 \pm 0.08$ & $1.58 \pm 0.19$ & $0.56 \pm 0.04$ \\
\hline Pentyl butyrate & $0.07 \pm 0.02$ & $0.06 \pm 0.01$ & $0.23 \pm 0.01$ & $0.13 \pm 0.01$ & $0.05 \pm 0.01$ & $0.05 \pm 0.01$ \\
\hline Hexyl butyrate & $0.77 \pm 0.20$ & $0.49 \pm 0.03$ & $4.81 \pm 0.48$ & $1.83 \pm 0.20$ & $0.48 \pm 0.07$ & $0.31 \pm 0.02$ \\
\hline Ethyl hexanoate & $0.01 \pm 0.01$ & $0.01 \pm 0.01$ & $0.04 \pm 0.01$ & ND & ND & $0.02 \pm 0.01$ \\
\hline 2-Methylbutyl acetate & $11.5 \pm 0.4$ & $10.3 \pm 1.1$ & $17.6 \pm 0.5$ & $17.0 \pm 1.3$ & $5.14 \pm 0.32$ & $6.57 \pm 0.54$ \\
\hline Methyl 2-methylbutyrate & $0.78 \pm 0.10$ & $0.17 \pm 0.05$ & $1.53 \pm 0.17$ & $0.26 \pm 0.03$ & $0.73 \pm 0.10$ & $0.07 \pm 0.02$ \\
\hline Ethyl 2-methylbutyrate & $0.02 \pm 0.01$ & $0.01 \pm 0.01$ & $0.08 \pm 0.01$ & $0.02 \pm 0.01$ & ND & ND \\
\hline Butyl 2-methylbutyrate & $2.25 \pm 0.06$ & $0.46 \pm 0.08$ & $3.57 \pm 0.12$ & $0.71 \pm 0.07$ & $1.57 \pm 0.16$ & $0.31 \pm 0.04$ \\
\hline Hexyl 2-methylbutyrate & $1.22 \pm 0.16$ & $0.58 \pm 0.06$ & $6.99 \pm 0.52$ & $2.05 \pm 0.18$ & $0.42 \pm 0.05$ & $0.19 \pm 0.02$ \\
\hline
\end{tabular}

$\overline{\mathrm{ND}}=$ not detected.

headspace samples collected from intact apples (Table 2). Butyl acetate was the most abundant ester detected from RA fruit followed by hexyl acetate and 2-methylbutyl acetate. Storage in static $1 \mathrm{kPa} \mathrm{O} \mathrm{O}_{2}$ reduced the production of most esters compared with apples stored in RA. Butyl acetate amounts from apples stored in static $1 \mathrm{kPa} \mathrm{O} 2$ were $29 \%, 30 \%$, and $7 \%$ of the amount detected from RA fruit after 60,90 and $120 \mathrm{~d}$ storage plus $7 \mathrm{~d}$ ripening at 20 ${ }^{\circ} \mathrm{C}$, respectively. The amounts of many other straight-chain esters also decreased after storage in static $1 \mathrm{kPa} \mathrm{O}_{2}$ compared with RAstored apples; however, the percent reduction varied among compounds. For example, propyl propanoate and hexyl hexanoate emissions from apples stored in static $1 \mathrm{kPa} \mathrm{O}_{2}$ were $15 \%, 20 \%$, and $14 \%$ and $89 \%, 61 \%$, and $75 \%$, respectively, of the amounts detected from RA fruit after 60, 90, and $120 \mathrm{~d}$ storage, while production of 2-methylbutyl acetate was similar after storage in static $1 \mathrm{kPaO} \mathrm{O}_{2}$ and RA after 60 and $90 \mathrm{~d}$ and higher after $120 \mathrm{~d}$ in static $1 \mathrm{kPa} \mathrm{O}$. Ethyl 2-methylbutyrate was detected in small amounts from apples stored in static $1 \mathrm{kPa} \mathrm{O}_{2}$ and RA through 90 $\mathrm{d}$ storage, but was not detected after $120 \mathrm{~d}$ in either storage regime. Net production of the other branched-chain esters was reduced by storage in $1 \mathrm{kPa} \mathrm{O}$ compared with RA-stored apples.

CA storage conditions affected the amount of esters emanating from 'Gala' apples. The total amount of esters detected from apples stored in air peaked at $90 \mathrm{~d}$ then declined (Fig. 2). Net ester production 1 and $7 \mathrm{~d}$ after removal from storage increased with $\mathrm{O}_{2}$ concentration for apples stored in static CA environments after 90 and $120 \mathrm{~d}$. After these storage durations, ester emission by apples stored at 1 and $1.9 \mathrm{kPa} \mathrm{O}_{2}$ was less than the amount detected from apples stored in 2.8 or $3.7 \mathrm{kPa} \mathrm{O}_{2}$. Apples stored in $3.7 \mathrm{kPa} \mathrm{O}$ and RA produced similar amounts of esters after $90 \mathrm{~d}$ but production by apples stored in $3.7 \mathrm{kPaO}_{2}$ was greater than $\mathrm{RA}$ apples after 120 $\mathrm{d}$ plus $1 \mathrm{~d}$ at $20^{\circ} \mathrm{C}$. No difference was observed in the total amount of esters detected from apples stored in dynamic atmospheres and the static $1 \mathrm{kPa} \mathrm{O} \mathrm{O}_{2}$ treatment $1 \mathrm{~d}$ after removal from storage regardless of storage duration. Ester production by apples from the dynamic and static $1 \mathrm{kPaO}_{2}$ treatments generally were among the lowest for all the CA treatments, except for $120 \mathrm{~d}$ storage plus $7 \mathrm{~d}$ ripening when the dynamic treatments had higher ester production compared with apples stored in 1 or $1.9 \mathrm{kPa} \mathrm{O}_{2}$.

Butyl acetate, 2-methylbutyl acetate, hexyl acetate and 1butanol have been identified as significant contributors to aroma of 'Gala' apples (Young et al., 1996). More butyl acetate is produced

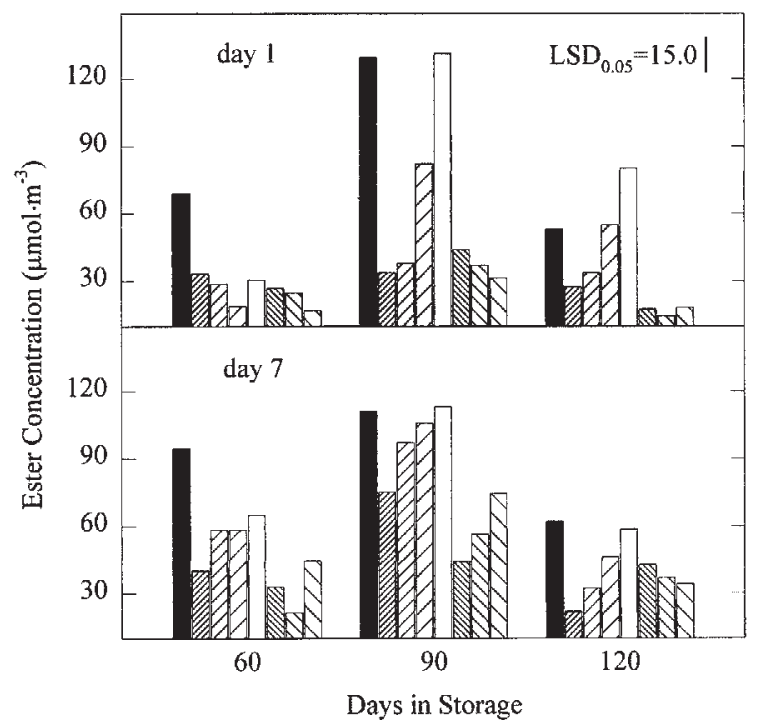

Fig. 2. Net ester production by 'Gala' apples following regular atmosphere (RA) or controlled atmosphere (CA) storage. Apples were removed from storage and esters emitted from intact fruit were determined after 1 or $7 \mathrm{~d}$ at $20^{\circ} \mathrm{C}$. Bars represent mean values based on analysis of four replicate samples normalized to $1 \mathrm{~kg}$ each. Values are $\mu \mathrm{mol} \cdot \mathrm{m}^{-3}$. Fisher's least significant difference value for significant treatment $\times$ storage duration $\times d$ ripened after storage interaction is indicated. 


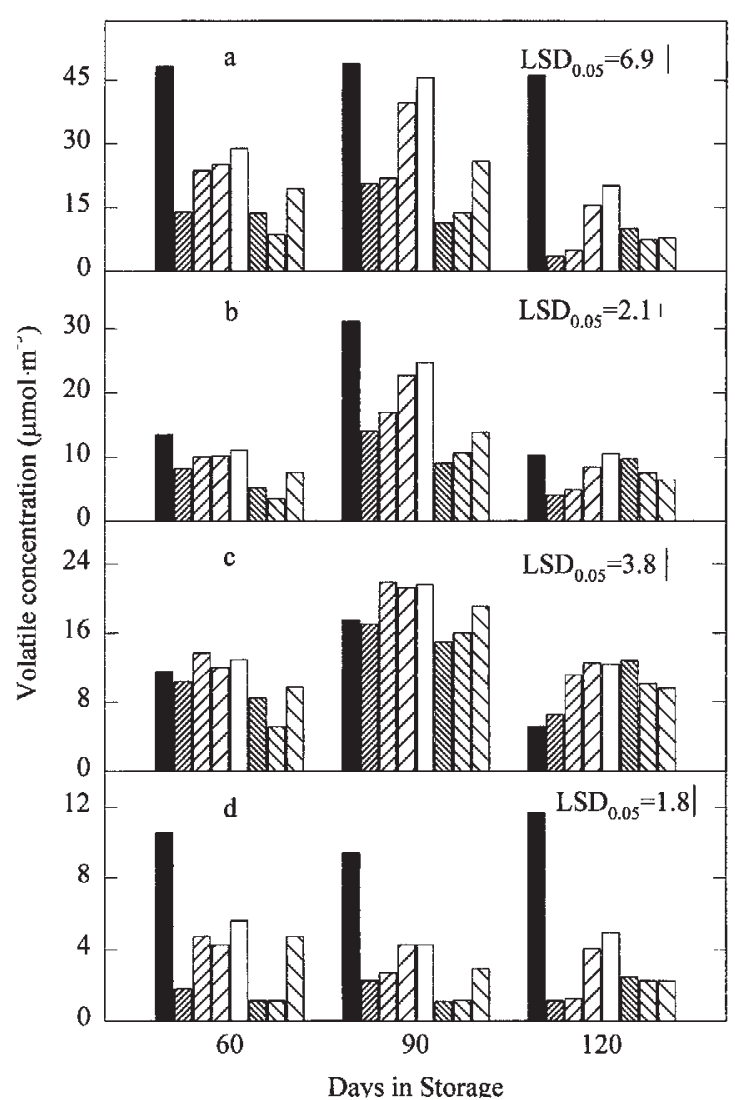

Fig. 3. Net production of butyl acetate (a), hexyl acetate (b), 2-methylbutyl acetate (c), and butanol (d) by 'Gala' apples following regular atmosphere (RA) or controlled atmosphere (CA) storage. Apples were removed from storage and sampled after $7 \mathrm{~d}$ at $20^{\circ} \mathrm{C}$. Bars represent mean values based on analysis of four replicate samples normalized to $1 \mathrm{~kg}$ each. Values are $\mu \mathrm{mol} \cdot \mathrm{m}^{-3}$. Fisher's least significant difference value for significant treatment $\times$ storage duration interaction is indicated.

by 'Gala' apples stored in RA than any other volatile ester (Fig. 3, Table 2). Amounts were consistent over the 120 -d storage period when samples were collected after $7 \mathrm{~d}$ at $20^{\circ} \mathrm{C}$ after storage. Emission of butyl acetate increased with static $\mathrm{CA} \mathrm{O}_{2}$ concentration. Butyl acetate emission by apples stored in 2.8 and $3.7 \mathrm{kPa} \mathrm{O}_{2}$ was greater than emissions from apples stored in 1 or $1.9 \mathrm{kPaO}_{2}$ after 90 and $120 \mathrm{~d}$ storage plus $7 \mathrm{~d}$ at $20^{\circ} \mathrm{C}$. More butyl acetate was emitted by apples in the $3 \mathrm{~d}$ per week dynamic treatment compared with the other dynamic treatments or the $1 \mathrm{kPa}$ static treatment after 60 and $90 \mathrm{~d}$ storage. After $120 \mathrm{~d}$ storage, however, no significant differences in butyl acetate emission were observed between the dynamic and static 1 and $1.9 \mathrm{kPa} \mathrm{O}_{2}$ treatments.

Emissions of hexyl acetate by fruit stored in RA peaked after 90 d (Fig. 3b). The amount of hexyl acetate increased with static $\mathrm{O}_{2}$ concentrations after 90 and $120 \mathrm{~d}$ storage. After $120 \mathrm{~d}$, the amount of hexyl acetate detected from apples stored in the dynamic atmospheres, static $2.8,3.7 \mathrm{kPa} \mathrm{O}_{2}$, or RA was significantly larger than the amounts from apples stored in static 1 or $1.9 \mathrm{kPa} \mathrm{O}_{2}$.

CA treatments had less impact on net 2-methylbutyl acetate production by 'Gala' apples compared with RA fruit (Fig. 3c). Amounts of 2-methylbutyl acetate emitted by apples stored in the 1.9 to $3.7 \mathrm{kPa}$ static $\mathrm{O}_{2}$ treatments were similar or higher than the amount detected from RA fruit. The amount of 2-methylbutyl acetate detected from apples stored under dynamic conditions was higher than amounts from apples stored in $\mathrm{RA}$ or $1 \mathrm{kPa} \mathrm{O}_{2}$ after $120 \mathrm{~d}$ storage.

Trends in butanol amounts detected after storage (Fig. 3d) were similar to those of butyl acetate for each storage treatment. The most butanol detected was in samples collected from RA fruit followed by the 2.8 and $3.7 \mathrm{kPa}$ static $\mathrm{O}_{2}$ treatments. The amount of butanol emitted from apples exposed to ambient air $3 \mathrm{~d}$ per week was higher compared with amounts detected from apples with the same exposure 1 or $2 \mathrm{~d}$ per week after 60 and $90 \mathrm{~d}$. No significant differences were observed between butanol amounts detected from apples stored in 1 or $1.9 \mathrm{kPa}$ static $\mathrm{O}_{2}$ or the dynamic treatments after $120 \mathrm{~d}$ in storage plus $7 \mathrm{~d}$ at $20^{\circ} \mathrm{C}$.

The presence of 1-methoxy-4-(2-propenyl) benzene (estragole, 4-allyl anisole) in 'Gala' apples (Young et al., 1996) was confirmed. This compound imparts a spicy, anise seed character to apple aroma (Williams et al., 1977). Apples stored in RA for 60 and $90 \mathrm{~d}$ plus $7 \mathrm{~d}$ at $20^{\circ} \mathrm{C}$ produced the largest amount of this compound compared with all CA treatments (Fig. 4). No treatment differences were observed $1 \mathrm{~d}$ after removal from storage. The amount of 1-methoxy-4-(2-propenyl) benzene detected increased significantly after $7 \mathrm{~d}$ at $20^{\circ} \mathrm{C}$ for RA and many CA treatments after 60 and $90 \mathrm{~d}$ storage. Apples stored in all the dynamic treatments produced higher amounts of 1-methoxy-4-(2-propenyl) benzene compared with fruit in the static CA or RA treatments after $120 \mathrm{~d}$ storage plus $7 \mathrm{~d}$ ripening. After $90 \mathrm{~d}$ storage plus $7 \mathrm{~d}$ ripening, apples exposed to ambient $\mathrm{O}_{2}$ for three 8-h periods per week produced more 1-methoxy-4-(2- propenyl) benzene than fruit exposed to ambient $\mathrm{O}_{2} 1$ or $2 \mathrm{~d}$ per week. After $120 \mathrm{~d}$ storage plus $7 \mathrm{~d}$ at $20^{\circ} \mathrm{C}$, production of 1-methoxy-4-(2-propenyl) benzene increased with frequency of exposure to $21 \mathrm{kPa} \mathrm{O}_{2}$.

Apples stored in static $1 \mathrm{kPa} \mathrm{O}_{2}$ and the dynamic treatments consistently had the highest firmness (Fig. 5). All the CA treatments resulted in significantly higher firmness compared with RA fruit after $60 \mathrm{~d}$ storage plus $1 \mathrm{~d}$ at $20^{\circ} \mathrm{C}$. No difference in firmness between apples stored in $\mathrm{RA}$ or static $3.7 \mathrm{kPaO}_{2}$ was observed after $7 \mathrm{~d}$ at $20^{\circ} \mathrm{C}$ for all storage durations. No firmness differences were observed between the static $1 \mathrm{kPa} \mathrm{O}_{2}$ and dynamic treatments at any time after removal from storage. Greater firmness loss by apples stored in the static $1.9,2.8$, and $3.7 \mathrm{kPa} \mathrm{O}_{2}$ treatments compared with apples in static $1 \mathrm{kPa} \mathrm{O}_{2}$ or dynamic atmospheres

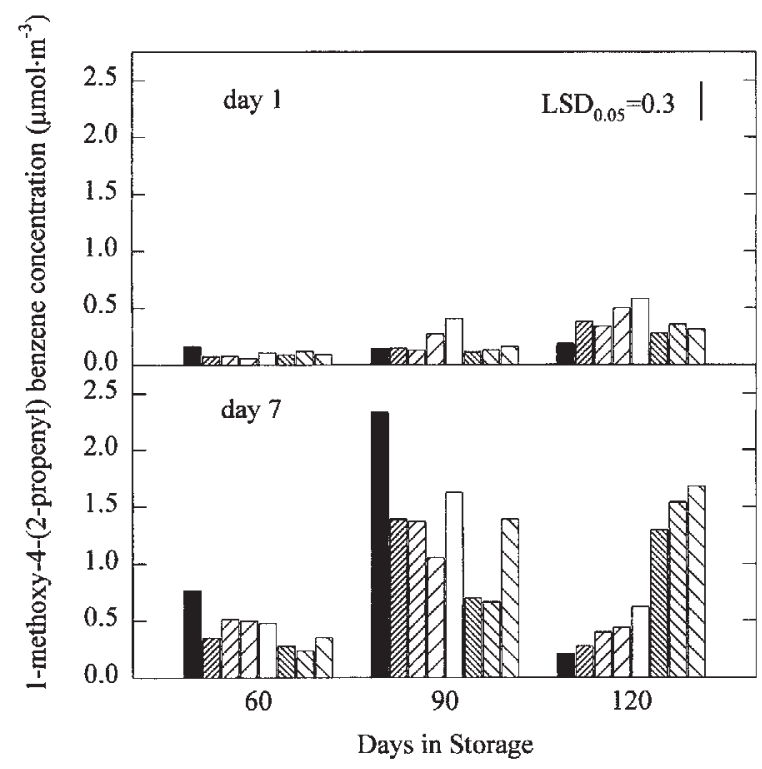

Fig. 4. Production of 1-methoxy-4-(2-propenyl) benzene by 'Gala' apples following regular atmosphere (RA) or controlled atmosphere (CA) storage. Apples were removed from storage and sampled after 1 or $7 \mathrm{~d}$ at $20^{\circ} \mathrm{C}$. Bars represent mean values based on analysis of four replicate samples normalized to $1 \mathrm{~kg}$ each. Values are $\mu \mathrm{mol} \cdot \mathrm{m}^{-3}$. Fisher's least significant difference value for significant treatment $\times$ storage duration $\times d$ ripened after storage interaction is indicated. 


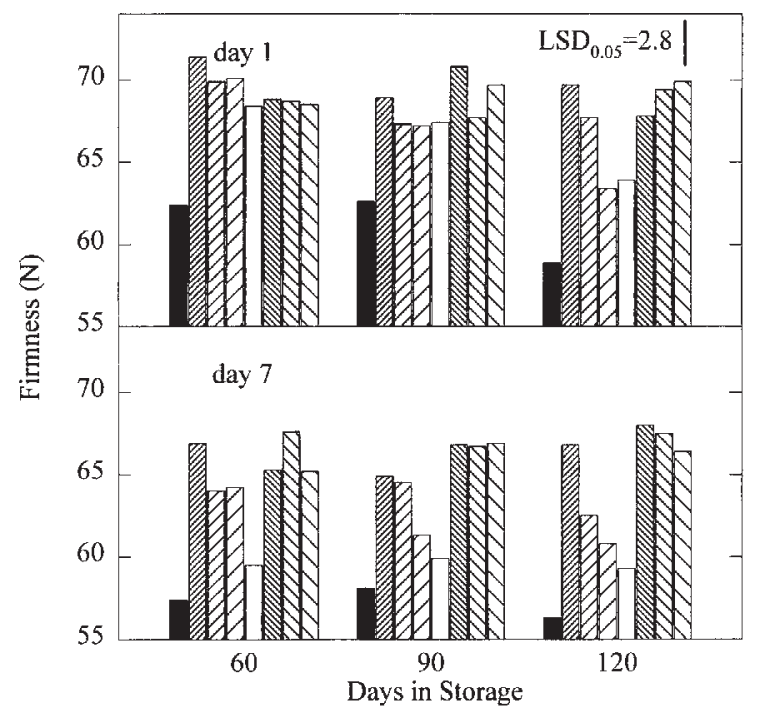

Fig. 5. 'Gala' apple firmness following regular atmosphere (RA) or controlled atmosphere (CA) storage. Apples were removed from storage and measured after 1 or $7 \mathrm{~d}$ at $20^{\circ} \mathrm{C}$. Bars represent mean values based on analysis of 20 individual apples. Fisher's least significant difference value for significant treatment $\times$ storage duration $\times \mathrm{d}$ ripened after storage interaction is indicated.

was apparent by $120 \mathrm{~d}$ storage plus $7 \mathrm{~d}$ at $20^{\circ} \mathrm{C}$.

TA of apples stored in air was significantly less than that of apples from all the CA treatments after $60 \mathrm{~d}$ storage plus $7 \mathrm{~d}$ at 20 ${ }^{\circ} \mathrm{C}$. However, there were no differences in TA between $\mathrm{CA}$ treatments (Fig. 6). No treatment differences were observed in SSC throughout the experiment (data not shown).

\section{Discussion}

Maturity at harvest is an important factor determining postharvest volatile production by apples (Dirinck et al., 1989; Hansen et al., 1992; Song and Bangerth, 1996; Vanoli et al., 1995; Yahia et al., 1990) and the response of apples to atmosphere manipulation during storage (Mattheis et al., 1995). 'Gala' apples were segregated at harvest based on ground color to select a uniform sample for the storage experiment. Harvest analyses (Table 1) indicated the 'Gala' apples used in this study met fruit quality criteria (i.e., firmness, TA, SSC, color) necessary for extended storage (Walsh et al., 1991; Plotto et al., 1995).

Ethylene production decreased with decreasing static $\mathrm{O}_{2}$ concentration after 90 and $120 \mathrm{~d}$ storage plus $1 \mathrm{~d}$ at $20^{\circ} \mathrm{C}$ (Fig. 1), a response similar to that reported for Cox's Orange Pippin (Stow, 1989). The similarity of ethylene production between apples stored in static $1 \mathrm{kPa} \mathrm{O}_{2}$ and dynamic treatments indicates that short, intermittent periods at ambient $\mathrm{O}_{2}$ are insufficient to reverse the impact of storage in $1 \mathrm{kPa} \mathrm{O}$ on ethylene production. The difference in ethylene production between fruit stored in the dynamic treatments and in static $1.9,2.8$, and $3.7 \mathrm{kPa} \mathrm{O}_{2}$ indicates no reciprocity of response for total $\mathrm{O}_{2}$ exposure during storage. The capacity of 'Gala' apples to produce ethylene recovers rapidly regardless of $\mathrm{O}_{2}$ storage regime. However, residual effects of $1 \mathrm{kPa}$ $\mathrm{O}_{2}$ storage, either static or as the dynamic treatment setpoint, were detectable after $120 \mathrm{~d}$ storage followed by $7 \mathrm{~d}$ ripening at $20^{\circ} \mathrm{C}$.

Most esters detected qualitatively and quantitatively from 'Gala' apples had straight-chain structures (Table 2). The negative impact of static $1 \mathrm{kPa} \mathrm{O}_{2}$ on poststorage ester production is evident as reduced emission of many straight-chain esters after $60 \mathrm{~d}$ storage plus $7 \mathrm{~d}$ at $20^{\circ} \mathrm{C}$. The magnitude that ester production is reduced varies for individual compounds, for example, net production of propyl propanoate is reduced more than hexyl hexanoate. Branchedchain ester production, except for 2-methylbutyl acetate, was also negatively affected by storage of 'Gala' apples at $1 \mathrm{kPa} \mathrm{O}_{2}$. Storage $\mathrm{O}_{2}$ concentration is a factor influencing production of straightchain esters after storage (Brackmann et al., 1993; Hansen et al., $1992 \mathrm{a}$; Streif and Bangerth, 1988) while storage $\mathrm{CO}_{2}$ concentration is a factor determining subsequent branched-chain ester production (Brackmann et al., 1993). Our data indicates there was a differential response of 'Gala' apples to $1 \mathrm{kPa} \mathrm{O}$ storage that results in variable poststorage production patterns within both of these groups of esters. The availability of precursors for ester synthesis, alcohols and carboxy CoAs (Yoshioka and Hashimoto, 1982), as well as substrate specificity of enzymes in the ester synthesis pathway are factors that may determine what compounds are produced. Reduction of ester production due to limited substrate availability occurs following prolonged low $\mathrm{O}_{2}$ storage of apples (Knee and Hatfield, 1981). Activity of the acyl alcohol transferase (EC 2.3.1.84) has also been shown to decrease during CA storage of apple fruit (Fellman et al., 1993).

'Gala' ester production after storage decreased with static $\mathrm{O}_{2}$ concentration (Fig. 2). The decrease relative to RA fruit was detectable after $60 \mathrm{~d}$ storage indicating impacts on 'Gala' aroma could be occurring after a relatively short period of CA storage. Differences among static $\mathrm{O}_{2}$ treatments were not detectable after $60 \mathrm{~d}$ storage indicating the effects of low $\mathrm{O}_{2}$ concentrations on pathways leading to ester production occur slowly. At $3.7 \mathrm{kPa} \mathrm{O}_{2}$ no difference in total ester production occurred relative to $\mathrm{RA}$ fruit after 90 and $120 \mathrm{~d}$ storage, suggesting the $\mathrm{O}_{2}$ threshold for reduced ester production by 'Gala' apples after longer duration static CA storage is between 2.8 and $3.7 \mathrm{kPa} \mathrm{O}_{2}$. Both of these $\mathrm{O}_{2}$ concentrations resulted in significant firmness loss over a $120 \mathrm{~d}$ storage period compared with apples stored at $1 \mathrm{kPa} \mathrm{O}_{2}$ (Fig. 5) and illustrates the difficulty in managing static storage environments to optimize poststorage 'Gala' aroma production while maintaining firmness.

Increased ester production by apples stored in the dynamic treatments compared to storage in static $1 \mathrm{kPa} \mathrm{O}_{2}$ was not detected until $120 \mathrm{~d}$ storage plus $7 \mathrm{~d}$ ripening at $20^{\circ} \mathrm{C}$ (Fig. 2). At this time total ester production by apples stored in the dynamic treatments

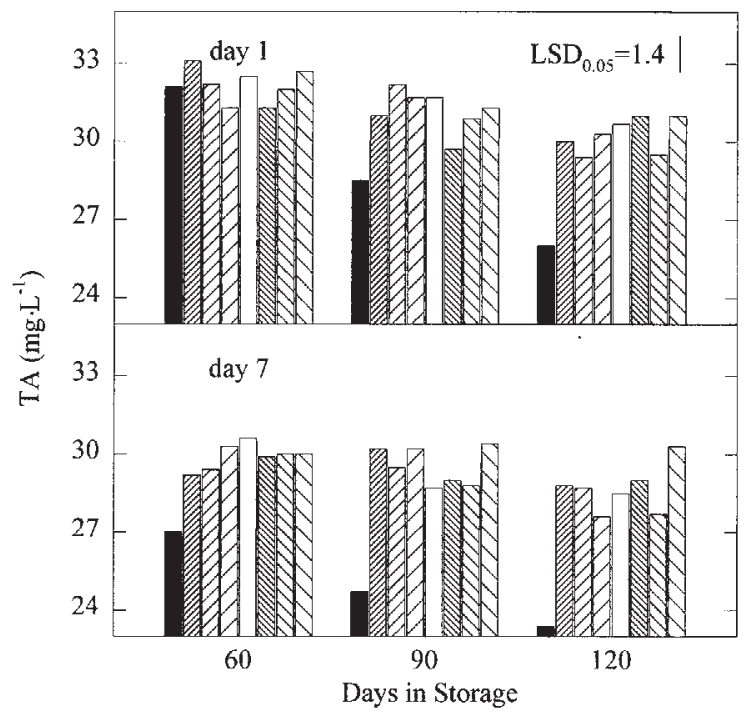

Fig. 6. 'Gala' apple titratable acidity (TA) following regular atmosphere (RA) or controlled atmosphere (CA) storage. Apples were removed from storage and TA was measured after 1 or $7 \mathrm{~d}$ at $20^{\circ} \mathrm{C}$. Bars represent mean values based on analysis of 20 individual apples. Fisher's least significant difference value for significant treatment $\times$ storage duration $\times d$ ripened after storage interaction is indicated. 
approached that of fruit stored in $2.8 \mathrm{kPa} \mathrm{O}_{2}$ while firmness was similar to apples stored in static $1 \mathrm{kPa} \mathrm{O}_{2}$. All the CA treatments reduced TA loss (Fig. 6), but the firmer apples stored in dynamic atmospheres and static $1 \mathrm{kPa} \mathrm{O}_{2}$ indicates the potential of managing storage environments to minimize firmness loss while enhancing aroma. Firmness loss and volatile production are considered to be ethylene-mediated responses in fruit, and manipulation of ethylene production by exogenous inhibitors (Bangerth and Streif, 1987 ) or genetic manipulation (Oeller et al., 1991) slows both processes. Dynamic atmosphere manipulation may allow maintenance of metabolic activity related to ester production while slowing firmness and TA loss, but as used in this study, the dynamic atmosphere effect on volatile production occurs slowly.

The CA environments used in this study had variable impacts on poststorage butyl acetate, hexyl acetate, 2-methylbutyl acetate and butanol production. The amounts of butyl acetate produced appeared to depend on the amount of butanol present (Fig. 3 a and d). Exposure of apple fruit to volatile acyl or branched-chain alcohols or fatty acid methyl esters has been demonstrated to increase the corresponding acetate ester (Bartley et al., 1985; Berger and Drawert, 1984; Rowan et al., 1996). Of the three esters identified by Young et al. (1996) as contributors to 'Royal Gala' aroma, production of hexyl acetate and 2-methylbutyl acetate is enhanced more than butyl acetate (and butanol) after $120 \mathrm{~d}$ storage plus $7 \mathrm{~d}$ at $20^{\circ} \mathrm{C}$ by dynamic storage conditions. A differential effect on metabolic events leading to synthesis of these esters appears to be a result of low $\mathrm{O}_{2}$ storage conditions.

Sensory panelists evaluating 'Gala' aroma identify a spicy, aniseed aroma (A. Plotto, personal communication). These are sensory descriptors previously shown to indicate the presence of 1 methoxy-4-(2-propenyl) benzene, also referred to as estragole or 4-allyl anisole, in apple fruit (Williams et al., 1977). This compound has previously been reported as a constituent of 'Royal Gala' apples (Young et al., 1996). One of the substrates for 1methoxy-4-(2-propenyl) benzene synthesis is the amino acid phenylalanine, produced via the shikimate pathway (Manitto et al., 1974). This pathway may be affected differently by CA compared to the metabolic processes culminating in ester synthesis. CA negatively affected synthesis of 1-methoxy-4-(2-propenyl) benzene as $\mathrm{O}_{2}$ concentration decreased only after $120 \mathrm{~d}$ storage when compared to production by RA fruit (Fig. 4). Production of 1methoxy-4-(2-propenyl) benzene by 'Gala' apples stored in RA and static CA up to $3.8 \mathrm{kPa}$ decreased markedly between 90 and $120 \mathrm{~d}$ storage, but the short exposures to ambient $\mathrm{O}_{2}$ results in production at relatively high amounts after $120 \mathrm{~d}$ storage followed by $7 \mathrm{~d}$ ripening at $20^{\circ} \mathrm{C}$. Intermittent exposure to ambient $\mathrm{O}_{2}$ may allow components of the shikimate pathway leading to 1 -methoxy4-(2-propenyl) benzene synthesis to be active after the synthesis capacity has declined in apples stored in RA or static CA.

The differential response of volatile production and softening among 'Gala' apples stored in dynamic versus static CA and RA storage may be due in part to the gas diffusion characteristics of this cultivar. 'Gala' apples have a low diffusive resistance compared with many other apple cultivars (Solomos, 1987). Assuming a closed calyx, the internal atmosphere equilibrates in response to external gas concentrations directionally from the peel into the cortex. The peel would equilibrate faster and therefore be at higher $\mathrm{O}_{2}$ concentrations longer during the exposures to ambient $\mathrm{O}_{2}$ compared to most of the cortex. Apple peel is the most productive tissue for volatile production (Guadagni et al., 1971), therefore brief relief from metabolic restrictions due to low $\mathrm{O}_{2}$ concentration may allow pathways leading to ester and other volatile production by peel tissue to remain functional at a higher level compared with apples stored continuously in $1 \mathrm{kPa} \mathrm{O}_{2}$. The slower equilibration of the cortex due to larger mass and restrictions of gas exchange through the peel (Solomos, 1987) may not allow cortex $\mathrm{O}_{2}$ concentration to increase to the threshold necessary for increased softening and acid loss during the 8-h exposures to ambient $\mathrm{O}_{2}$.

CA technology has been used commercially to generate and maintain static low $\mathrm{O}_{2}$ conditions. Advances in CA generating and control technology have removed technical barriers to the rapid and precise imposition of low $\mathrm{O}_{2}$ conditions. No negative impacts of dynamic atmospheres as imposed in this work were observed. The question of significant fruit quality benefits from use of these regimes remains to be answered. The enhanced production of esters and other volatile compounds from 'Gala' apples determined analytically does not provide sensory information to indicate if these treatments improved fruit aroma and/or flavor as perceived by sensory analysis. At some frequency of release from the low oxygen setpoint, the benefits of low $\mathrm{O}_{2}$ storage on fruit firmness, TA, and other quality factors attributable to low $\mathrm{O}_{2}$ storage will degrade. The dynamic conditions resulting in excessive degradation of fruit quality compared with static $1 \mathrm{kPa} \mathrm{O}_{2}$ remain to be defined.

\section{Literature Cited}

Abeles, F.W., P.W. Morgan, and M.E. Saltveit. 1992. Ethylene in plant biology. Academic Press, New York.

Bangerth, F. 1984. Changes in sensitivity for ethylene during storage of apple and banana fruits under hypobaric conditions. Sci. Hort. 24:151163.

Bangerth, F. and J. Streif. 1987. Effect of aminoethoxyvinylglycine and low-pressure storage on the post-storage production of aroma volatiles by Golden Delicious apples. J. Sci. Food Agr. 41:351-360.

Bartley, I. M., P.G. Stoker, A.D.E. Martin, S.G.S. Hatfield, and M. Knee. 1985. Synthesis of aroma compounds by apples supplied with alcohols and methyl esters of fatty acids. J. Sci. Food Agr. 36:567-574.

Berger, R.G., and F. Drawert. 1984. Changes in the composition of volatiles by post-harvest application of alcohols to 'Red Delicious' apples. J. Sci. Food Agr. 35:1318-1325.

Brackmann, A., J. Streif, and F. Bangerth. 1993. Relationship between a reduced aroma production and lipid metabolism of apples after longterm controlled-atmosphere storage. J. Amer. Soc. Hort. Sci. 118:243247.

Brown, D.S., J.R. Buchanan, and J.R. Hicks. 1966. Volatiles from apple fruits as related to variety, maturity, and ripeness. Proc. Amer. Soc. Hort. Sci. 88:89-104.

Dirinck, P., H. De Pooter, and N. Schamp. 1989. Aroma development in ripening fruits, p. 23-34. In: R. Teranishi, R.G. Buttery, and F. Shahidi (eds.). Flavor chemistry: Trends and developments. ACS Symp. Ser. 388, Amer. Chem. Soc., Washington, D.C.

Fellman, J.K., D.S. Mattinson, B.C. Bostick, J.P. Mattheis, and M.E Patterson. 1993. Ester biosynthesis in 'Rome' apples subjected to lowoxygen atmospheres. Postharvest Biol. Technol. 3:201-214.

Gorny, J.R. and A.A. Kader. 1996. Controlled-atmosphere suppression of ACC synthase and ACC oxidase in 'Golden Delicious' apples during long-term cold storage. J. Amer. Soc. Hort. Sci. 121:751-755.

Guadagni, D.G., J.L. Bomben, and J.S. Hudson. 1971 . Factors influencing the development of aroma in apple peels. J. Sci. Food Agr. 22:111-115. Halder-Doll, H. and F. Bangerth. 1987. Inhibition of autocatalytic $\mathrm{C}_{2} \mathrm{H}_{4}$ biosynthesis by AVG applications and consequences on the physiological behaviour and quality of apple fruits in cool storage. Sci. Hort. 33:87-96.

Hansen, K. and L. Poll. 1993. Conversion of L-isoleucine into 2-methylbut2-enyl esters in apples. Lebensm. Wiss. Technol. 26:178-180.

Hansen, K., L. Poll, and M.J. Lewis. 1992a. The influence of picking time on the post-harvest volatile ester production of 'Jonagold' apples. Lebensm. Wiss. Technol. 25:451-456.

Hansen, K., L. Poll, C.E. Olsen, and M.J. Lewis. 1992b. The influence of 
oxygen concentration in storage atmospheres on the post-storage volatile ester production of 'Jonagold' apples. Lebensm. Wiss. Technol. 25:457-461.

Knee, M. and S.G.S. Hatfield. 1981. The metabolism of alcohols by apple fruit tissue. J. Sci. Food Agr. 32:593-600.

Lidster, P.D., H.J. Lightfoot, and K.B. McRae. 1983. Production and regeneration of principal volatiles in apples stored in modified atmospheres and air. J. Food Sci. 48:400-410.

Manitto, P., D. Monti, and P. Gramitica. 1974. Biosynthesis of phenylpropanoid compounds. Part I. Biosynthesis of eugenol in Ocimum basilicum L. J. Chem. Soc. Perkin Trans 1:1727-1731.

Mattheis, J.P., D.A. Buchanan, and J.K. Fellman. 1991. Change in apple fruit volatiles after storage in atmospheres inducing anaerobic metabolism. J. Agr. Food Chem. 39:1602-1605.

Mattheis, J.P., D.A. Buchanan, and J.K. Fellman. 1995. Volatile compound production by Bisbee Delicious apples after sequential atmosphere storage. J. Agr. Food Chem. 43:194-199.

Myers, M.J., P. Issenberg, and E.L. Wick. 1970. L-Leucine as a precursor of isoamyl alcohol and isoamyl acetate, volatile aroma constituents of banana fruit discs. Phytochemistry 9:1693-1600.

Oeller, P.W., L.M. Wong., L.P. Taylor, D.A. Pike, and A. Theologis. 1991. Reversible inhibition of tomato fruit senescence by antisense RNA. Science 254:437-439.

Patterson, B.D., S.G.S. Hatfield, and M. Knee. 1974. Residual effects of controlled atmosphere storage on the production of volatile compounds by two varieties of apples. J. Sci. Food Agr. 25:843-849.

Plotto, A.P., A.N. Azarenko, J.P. Mattheis, and M.R. McDaniel. 1995. 'Gala', Braeburn' and 'Fuji' apples: maturity indices and quality after storage. Fruit Var. J. 49:133-142.

Rowan, D.D., H.P. Lane, J.M. Allen, S. Fielder, and M.B. Hunt. 1996 Biosynthesis of 2-methylbutyl, 2-methyl-2-butenyl, and 2methylbutanoate esters in Red Delicious and Granny Smith apples using deuterium-labeled substrates. J. Agr. Food Chem. 44:3276-3285.

Smith, S.M. 1984. Improvement of aroma of Cox's Orange Pippin apples stored in low oxygen atmospheres. J. Hort. Sci. 59:515-522.

Solomos, T. Principles of gas exchange in bulky plant tissues. 1987. HortScience 22:766-771.

Song, J. and F. Bangerth. 1996. The effect of harvest date on aroma compound production from 'Golden Delicious' apple fruit and relationship to respiration and ethylene production. Postharvest Biol. Technol. $8: 259-269$.
Stow, J. 1989. Effects of oxygen concentration on ethylene synthesis and action in stored apple fruits. Acta Hort. 258:97-106.

Streif, J. and F. Bangerth. 1988. Production of volatile aroma substances by 'Golden Delicious' apple fruits after storage for various times in different $\mathrm{CO}_{2}$ and $\mathrm{O}_{2}$ concentrations. J. Hort. Sci. 63:193-199.

Tressl, R., F. Drawert, W. Heimann, and R. Emberger. 1970a. The biogenesis of aroma compounds by plants and fruit. VIII. Biogenesis of banana aroma compounds. Lebensm. Unters.-Forsch. 144:4-9.

Tressl, R., R. Emberger, F. Drawert, and W. Heimann. 1970b. Biogenesis of plant and fruit flavors. XI. Incorporation of leucine-14C and valine14C in banana flavors. Z. Natureforsch. B 25:704-707.

Vanoli, M., C. Visai, and A. Rizzolo. 1995. The influence of harvest date on the volatile composition of 'Starkspur Golden' apples. Postharvest Biol. Technol. 6:225-234.

Walsh, C.S., B. Slater, T. Solomos, and A. Thompson. 1991. Determining 'Gala' maturity for different storage regimes. GoodFruit Grower 42:6-10.

Willaert, G.A., P.J. Dirinck, H.L. DePooter, and N.N. Schamp. 1983. Objective measurement of aroma quality of Golden Delicious apples as a function of controlled-atmosphere storage time. J. Agr. Food Chem. 31:809-813.

Williams, A.A., O.G. Tucknott, and M.J. Lewis. 1977. 4-methoxyallylbenzene: An important aroma component of apples. J. Sci. Food Agr. 28:185-190.

Williams, M.W. and M.EPatterson. 1962. Internal atmosphere in 'Bartlett' pears stored in controlled atmospheres. Proc. Amer. Soc. Hort. Sci. 81:129-136

Yahia, E.M., F.W. Liu, and T.E. Acree. 1991. Changes of some odouractive volatiles in low-ethylene controlled atmosphere stored apples. Food Sci. Technol. 24:145-151.

Yahia, E.M., T.E. Acree, and F.W. Liu. 1990. The evolution of some odour-active volatiles during the maturation and ripening of apples on the tree. Lebensm. Wiss. Technol. 23:488-493.

Yahia, E.M. 1991. Production of some odor-active volatiles by 'McIntosh' apples following low-ethylene controlled atmosphere storage. HortScience 26:1183-1185.

Yoshioka, K. and N. Hashimoto. 1982. Ester formation by alcohol acetyl transferase from brewer's yeast. II. Properties of alcohol acetyl transferase. Res. Rest. Lab. Karin Brew. Co. 25:7-12.

Young, H., J.M. Gilbert, S.H. Murray, and R.D. Ball. 1996. Causal effects of aroma compounds on Royal Gala apple flavours. J. Sci. Food Agr. 71:329-336. 